\title{
Paraeducators Transition From Silent Partners to Collaborators with Science Teachers in Urban Middle Schools
}

\author{
Kimberly A. Staples \\ Kansas State University \\ kstaples@ksu.edu
}

\begin{abstract}
Within middle school classrooms a diverse body of students require specialized instruction and science teachers with unique abilities to implement a reform-based science curriculum. To achieve the goal of success for all, students who are English language leaners and with exceptionalities, such as learning disabilities, and emotional and behavioral disorders, are often assigned paraeducators to support science learning. However, professional development often focuses on immersing paraeducators through a broad model of curricular modifications and general support strategies. This study reports findings of a three-year professional development project for middle level science teachers and paraeducators designed to increase science conceptual understanding and inquiry skills development. The overarching goals were to: 1) increase middle level science teachers ability to explain science concepts, and 2) develop paraeducator's ability to directly assist in delivering inquiry-based science for students with Individualized Educational Plans identified with learning disabilities and emotional and behavioral disorders. A total of 13 science teachers collaborated with 11 paraeducators to identify practices impeding reform-based science instruction, address misconceptions, and modify delivery of instruction and assessment. The model for collaborating with science teachers enabled paraprofessionals to experience science as inquiry and expand their understanding of the vital role paraeducators have in supporting science learning. This mixed methods research design utilized data collected from the STEBI-A [and modified version for paraeducators], RTOP, and reflective journals to determine project impact. Analyses of the data reveal change in conceptual understanding, perceptions, and methodologies by which teachers and paraeducators collaborate to implement science instruction. The model demonstrates strategies for shifting the paradigm of paraeducators as silent partners to active participants in teaching inquiry-based science in middle schools.
\end{abstract}

Keywords: middle level science teacher, paraeducator, science teacher collaboration

\section{INTRODUCTION}

In response to the call for increasing the number of students entering STEM fields in the U.S., diverse pathways must be provided to encourage and prepare students from culturally and linguistically diverse backgrounds and students with learning disabilities and emotional and behavioral disorders to enter and succeed in fields such as engineering. This paper describes the results of a threeyear science teacher-paraeducator professional development project, in which science and engineering concepts were used to 
Vol. 17, No. 1 - 2013

Journal of Science Education for Students with Disabilities increase science achievement among diverse learners in an urban school district. According to the National Council for Accreditation of Teacher Education (NCATE, 2008), the licensing agency for teacher certification programs at U. S. colleges and universities, examples of diverse populations include students based on ethnicity, race, socioeconomic status, gender, exceptionalities, language, and geographical area.

This professional development model, which included engineering, special education, and science education faculty partnered with middle level science teachers and paraeducators, presents a viable method of integrating engineering concepts into the curriculum while simultaneously improving science instruction and student achievement (Cantrell, Pekcan, Itani, and Valasquez-Brayant, 2002). A total of 13 middle school science teachers and 11 paraeducators participated in the professional development project. The overall goal of the project, using engineering concepts, was to identify the key factors that influence paraeducator support of inquirybased science instruction for culturally and linguistically diverse students and students with learning disabilities and emotional and behavioral disorders. Quantitative and qualitative data results reveal an area commonly disregarded in the support of student learning yet critical in the process of implementing inquiry-based science for diverse learners. The research presents a model for preparing middle level science teachers and paraeducators to form true collaborative teams that increase science achievement among diverse students in an urban district.

The theoretical framework to support this col- laborative science professional development model is based on a body of research supporting Professional Learning Communities (NCTAF, 2010). Foundational to supporting this collaborative model was creating a nexus between high quality professional development and instructional resources, which in this model improved instruction and student achievement (Banilower, E., Boyd, S., Pasley, J. and Weiss, I. (2006). The researcher sought to identify variables that affect collaborative efforts between science teachers and paraeducators to support science inquiry instruction for diverse students in grades 6-8. The project combined qualitative and quantitative methods of assessing the efficacy of utilizing the Reverse Design-Build-Test, Tower Challenge, and Bridge Building to communicate science content among teachers, paraeducators, and students.

Based on Guskey's (2000) model for levels of professional development, 13 science teachers and 11 paraeducators participated in a three-year, two-week summer science institute, with follow-up support by engineering and education faculty during each academic year. Quantitatively, science teachers and paraeducators completed a pre and post-test Science Teaching Efficacy and Belief Instrument (STEBI-A) for each phase of the project. The STEBI-A measured self-efficacy of science teachers based on how they regarded themselves and their roles in science teaching (Enochs \& Riggs, 1990). Science teachers with high self-efficacy tend to teach in ways that are consistent with a constructivist approach to learning. Higher self-efficacy is consistent with teachers implementing inquiry-based strategies and student-centered classrooms. Science teachers with higher effi- 
cacy believe that they can help students overcome barriers to learning science. Also, the STEBI-A was modified to measure self-efficacy and outcome expectancy of paraeducators for each phase of the project. Specifically the researcher sought to identify variables affecting collaboration between paraeducators and science teachers as well as factors that influence paraeducator ability to support science inquiry instruction in classrooms with high levels of diversity.

During each academic year of the project, the Reform Teacher Observation Protocol (RTOP) was used to determine the degree of change in science teacher propositional and procedural knowledge. This instrument is a twenty-five item protocol using a 100-point scale. There are three main categories in the protocol: (1) Lesson Design and Implementation, (2) Content, and (3) Classroom Culture. The Content category contains two subsections, Propositional Knowledge and Procedural Knowledge. The instrument has been used in the evaluation of university and K-12 science classrooms (Piburn, Sawada, Falconer, Turley, Benford, and Bloom, 2000). The RTOP was also modified for paraeducators during science lesson observations to determine communication of science content and interactions with diverse learners. Qualitatively, following each professional development session during the two-week summer science institute science teachers and paraeducators completed reflections, which were analyzed using Strauss and Corbin's (1990) procedures and techniques for grounded theory. Reflections were used to determine change in conceptual understanding and impact of experiencing professional development as a collaborative team.

\section{METHOD}

\section{Participants}

Middle level science teachers (13), grades 6-8, were recruited for participation through district level announcements by the science coordinator. A total of eleven middle level paraeducators were invited to participate by teachers and district level special education announcements. Certification of teachers included K-6, K-8, K-9, biology, chemistry, elementary education, secondary education, social studies/language arts K-12, and special education. Endorsements include Highly Qualified Math and Science, and English as a Second Language. There were 10 middle level schools represented in the study. Three of the 13 middle level teachers taught at the same school.

\section{Professional Development Model}

During the first phase (Year 1) of the project, middle level science teachers experienced indepth science content immersion and process skills enhancement consistent with the fundamental tenets of the National Science Education Standards (NRC, 1996) for middle level [grades 6-8] science teaching. This was accomplished with faculty engaging teachers in critical thinking sessions to examine abstract concepts across biology, physics, earth and space science and engineering. Through this content immersion process science teachers identified factors influencing implementation and content delivery during each step in the process, while identifying the "perceived" role of the paraeducator during instruction and assessment (Nevin, Villa, Thousand, 2009). Consistent with outcomes of implementing professional learning communities, science teachers "freely" engaged in discus- 
Vol. 17, No. 1 - 2013

Journal of Science Education for Students with Disabilities sion of science content for deeper level understanding as well as eliciting pedagogical content knowledge of how to teach concepts of engineering (NCTAF, 2010). This led to an increased level of preparedness to teach concepts, which was later observed during classroom observations by education and engineering faculty during site visits.

During the second phase, (Year 2) a cohort of 11 paraeducators cycled into the project during the two-week summer science institute. For the first week the paraeducators received in-depth professional development to formally demonstrate and provide experiential learning of science process skills and key science content for grades 6-8. During the second week paraeducators formed collaborative teams with science teachers [Teacher-Paraeducator Collaboration, TPC] to identify factors adversely affecting student conceptual and process skills development. During each step in the process, the TPC identified factors that influenced the communication of engineering concepts based on student diverse backgrounds as well as teacher-paraeducator interactions. As an effective support system for student science learning, paraeducators' professional development addressed science conceptual understanding and science processes development. As an extended learning experience for engineering content integration, the Teacher-Paraeducator Collaboration (TPC) was formed during the tower challenge activity. Based on Bittel and Hernandez's (2006) strategies for differentiating instruction and assessment, science teachers and paraeducators developed action plans consisting of differentiated assessment strategies to integrate engineering concepts into the curriculum.
During the final phase, (Year 3), the TPC transitioned to the Bridge Building Design project. During the two-week summer science institute science teachers focused on defining for themselves the supportive role paraeducators would fulfill to help students learning disabilities and attention deficit disorder develop problem-solving strategies and science language acquisition. Engineering faculty demonstrated the integration of online bridge building simulations to promote critical thinking skills. Paraeducators received professional development in online simulations in tandem with strategies for communicating with students with special learning and English language needs. Co-teaching roles were established to demonstrate how paraeducators support science teacher implementation of inquiry-based science instruction, which included assisting students in designing towers using online simulations.

Based on Guskey's (1998) model of implementing professional development, it was evident through collaboration and reflective discussions that science teachers had developed a "new" role for paraeducators in the classroom. Science teachers received additional support during the academic year from engineering faculty through site visits and online discussion to model how to assist diverse learners in the classroom using online simulations.

During each phase of the project, science teachers and paraeducators completed pre and posttest STEBI-A (modified version), and journal reflections to reveal change in conceptual understanding and impact of collaboration. Site visits were conducted during the school year to complete the RTOP (re- 
vised version) for science teachers. Revised versions of the STEBI-A and RTOP were utilized for paraeducators.

\section{RESULTS}

Overall, the project successfully established 11 teacher-paraeducator collaborations to support student science learning. Quantitatively STEBI-A and RTOP pre and posttest scores revealed an increase in PSTE and STOE. (see figure at bottom of page)

The following is a report of eight RTOP observations during the final year of the project. The researcher and engineering faculty discussed the lesson and reviewed each category of the RTOP with the teachers following the observation. Propositional Knowledge was observed at the upper range of the "Very Descriptive" level using the RTOP (Turley, Piburn, \& Sawada, 2001). This instrument measures the degree of reform in science teaching. This section of the RTOP (Content) is divided into two subsections, propositional knowledge and procedural knowledge. Scores range from 0-4 (Never Occurred to Very Descriptive). To measure science conceptual understanding, section IV, subsection
Propositional Knowledge, was used to determine if:

- The lesson involved fundamental concepts of the subject matter.

- The lesson promoted strongly coherent conceptual understanding.

- The teacher had a solid grasp of the subject matter content inherent in the lesson.

- Elements of abstraction (i.e., symbolic representation, theory building) were encouraged when it was important to do so.

- Connections with other content disciplines and/or real phenomena were explored and valued.

During the academic year the researcher observed content lessons consisting of earth, life, and physical science content. Average scores for this section (IV) of the RTOP are:

- Lesson 1 - Potential and Kinetic Energy (4.0)

- Lesson 2 - Disease Fighters (4.0)

- Lesson 3 - Effect of Sun's Energy on Earth's Atmosphere (3.2)

- Lesson 4-Cellular Organization (4.0)

- Lesson 5 - Transfer of Energy: Forms of Waves (4.0)

- Lesson 6-Concept of Weathers (4.0)

- Lesson 7 - Creating Mixtures: Wood Products (4.0)

- Lesson 8 - Our Bodies Our Health (4.0)

\section{Science Teacher STEBI-A Average Scores} (13)

- Pre and Posttest Personal Science Teaching Efficacy (PSTE $=55,57.0$ )

- Pre and Posttest Science Teaching Outcome Expectancy (STOE $=48.0$, 54.0)
Paraeducator STEBI (Modified) Average Scores (11)

- Pre and Posttest Personal Science Teaching Efficacy (PSTE $=48.0,52.0$ )

- Pre and Posttest Science Teaching Outcome Expectancy $(\mathrm{STOE}=45,49.0)$ 
The RTOP (Turley, Piburn, \& Sawada, 2001), Part IV (Content) also contains a subsection titled

Procedural Knowledge, which measures [on a scale of 1-4] if teachers promote the following:

- Students used a variety of means (models, drawings, graphs, concrete materials, manipulatives, etc.) to represent phenomena.

- Students made predictions, estimation and/or hypotheses and devised means for testing them.

- Students were actively engaged in thought-provoking activity that often involved critical assessment of procedures.

- Students were reflective about their learning

- Intellectual rigor, constructive criticism, and the challenging of ideas were valued.

Average scores for this section (IV) of the RTOP are:

- Lesson 1 - Potential and Kinetic Energy (4.0)

- Lesson 2 - Disease Fighters (4.0)

- Lesson 3 - Effect of Sun's Energy on Earth's Atmosphere (3.4)

- Lesson 4-Cellular Organization (3.8)

- Lesson 5 - Transfer of Energy: Forms of Waves (4.0)

- Lesson 6 - Concept of Weathers (4.0)

- Lesson 7 - Creating Mixtures: Wood Products (4.0)

- Lesson 8 - Our Bodies Our Health (4.0)

Science pedagogical content knowledge was documented through site observations of science teaching using the RTOP, Part III,
Lesson Design and Implementation, and follow-up interview questions with the classroom teachers. This section evaluates the degree of reform consistent with the National Science Education Standards for lesson design and implementation for the following:

- The instructional strategies and activities respected students' prior knowledge and the preconception inherent therein.

- The lesson was designed to engage students as members of a learning community.

- In this lesson, student exploration preceded formal presentation.

- This lesson encouraged students to seek and value alternative models of investigation or problem solving.

- The focus and direction of the lesson was often determined by ideas originating with students.

Using the RTOP, average scores for Part III, Lesson Design and Implementation, are:

- Lesson 1 - Potential and Kinetic Energy (4.0)

- Lesson 2 - Disease Fighters (3.8)

- Lesson 3 - Effect of Sun's Energy on Earth's Atmosphere (3.2)

- Lesson 4 - Cellular Organization (3.6)

- Lesson 5 - Transfer of Energy: Forms of Waves (4.0)

- Lesson 6 - Concept of Weathers (4.0)

- Lesson 7 - Creating Mixtures: Wood Products (4.0)

- Lesson 8 - Our Bodies Our Health (3.8)

Science pedagogical content knowledge was documented through site observations of paraeducators providing support using the RTOP, Part III, and follow-up interview 
questions. This section evaluates the degree of reform consistent with the National Science Education Standards for lesson design and implementation for the following:

- The instructional strategies and activities respected students' prior knowledge and the preconception inherent therein.

- The lesson was designed to engage students as members of a learning community.

- In this lesson, student exploration preceded formal presentation.

- This lesson encouraged students to seek and value alternative models of investigation or problem solving.

- The focus and direction of the lesson was often determined by ideas originating with students.

Using the RTOP, average scores for Part III, Support for Lesson Implementation are:

- Lesson 1 - Potential and Kinetic Energy (4.0)

- Lesson 3 - Effect of Sun's Energy on Earth's Atmosphere (4.0)

- Lesson 7 - Creating Mixtures: Wood Products (4.0)

- Lesson 8 - Our Bodies Our Health (4.0)

Qualitative data results reveal middle level science teachers held misconceptions of the vital role the paraeducator fulfills in supporting student science learning. Communication must become an active and integral component of science instruction between the teacher and paraeducator. Planning with the paraeducator is critical to success of the TeacherParaeducator Collaboration (TPC). Qualitative data results reveal paraeducators desire knowledge of the science content and process skills required to support students with from culturally and linguistically diverse backgrounds, students with learning disabilities, and students with emotional and behavioral disorders. This area was commonly disregarded in the professional development of paraeducators for the science classroom in the district.

Paraeducators were empowered to "expand" their traditionally viewed "limited" role in science teaching. Through reflective journaling, each paraeducator directly reported a need to understand the science content and methodologies used during science teaching. This new role for paraeducators as collaborators enabled them to confidently convey science and engineering concepts and process skills during inquiry science teaching. Participants in the project demonstrated a high degree of ownership of science content and ability to support student science learning. Paraeducators dismissed their perceived role as "silent" partners and transitioned to true collaborators.

Follow-up interviews with principals reveal change in views building-wide among other content area teachers. Middle level teachers began to request paraeducators who participated in the project to work with students in their classrooms. At the end of the project teachers and paraprofessionals evaluated the implementation of Improvement Action Plans to demonstrate ability to adapt, deliver, and support science instruction appropriate for students based on cognitive level. Also paraeducators experienced success in strengthening collaborative efforts with the classroom teacher as well as implementing 
Vol. 17, No. 1 - 2013

Journal of Science Education for Students with Disabilities activities with students with learning disabilities, which included auditory and visual processing disorders. Based on reported documentation as well as site visits, teachers integrated methodologies from the science institutes based on standards and indicators required by the district. Vignettes from middle level science teachers further reveal impact of the project:

"This past year I taught 8th grade science which primarily focused on earth science. Class size ranges from 24 to 30 with inclusion of SPED and ESL students. I had two classes with 6-8 ESL students in each and SPED students number between two and six in all the classes. An ESL paraprofessional was available for two classes and a SPED paraprofessional was in 3 of my classes. Making and recording data was heavily emphasized throughout the year. Student performance was outstanding on environmental issues related to understanding the importance of cycles. I was able to summarize and confirm understanding through student work products. Students prepared cell models using everyday materials and most of the students demonstrated their understanding of the key organelles. One goal was to increase the level of student engagement by differentiating instruction and providing more upfront hands-on exploration activities. Many more labs were implemented as compared to the previous year." [Middle level science teacher, \#1]

"The students were all eighth graders. The total students on the class rosters were one hundred seventy-four students. The classes were eighty-seven percent Hispanic, eleven percent Black, and two percent other. The other categories include but are not limited to Somalia, Kenyan, Vietnamese, and Thai. We are a language and culturally diverse student body. Focus (Science Content Areas and/or Process [Inquiry] Skills: The content area for eighth grade is Earth Science. We follow the standards for the state. This year there were twenty-four units, which included ninety-six benchmarks (I can....statements) developed by our district. The process skills are included in these units and benchmarks. Some of the process skills covered are designing experiments, constructing a data table, Operationally defining vocabulary and variables as well as observing, communicating, and using metric measurements. Curricular Materials Utilized: The materials required are those that support the State Standards for the middle school science curriculum, especially Earth Science. Materials from the SEPUP Earth Science Issues were the major resource for the lab activities. Key Instructional Activities: From the project and the SEPUP resources, we implemented Observing Natural Resources, investigations 12, 15, and 16. We also did activities from the Diverse Learner section. Some of the activities were Evaluating Group Interaction and using the lab equipment. Strategies used to support science instruction included differentiating instruction, peer tutoring, and grouping. My goals are evaluated at seventyfive percent accuracy. The goal was met with ninety-eight percent success." [Middle level science teacher, \#2]

\section{Sample vignettes from paraeducators}

"Developed a team Approach with the science teacher and principal. I met with Lead Teacher, and Principal, with Science Teach- 
ers. Informed them of the information I received from the project. Met with Science Teachers and presented a power point about activities that we experienced through the project. Pulled out small groups to work with. During science worked one on one with some students. Used resources such and web sites... also used the K-8 Science book received last year to help explain some areas of Science. Used peers, asked questions, and rephrased to check for student science understanding. Did maintain a journal. Wrote down when some modifications were used for lessons and test. Shorten lessons and modification of tests, use other resources, and rephrasing to put the lessons in their world." [Paraeducator, \#1]

"I matched the learner's developmental needs (group the learners together that have close to the same needs.). Connect the learners' learning experience to current and past experiences. Met with the lead teacher to discuss and created an instructional plan and activities from the project to meet the learner needs. I matched the students' developmental needs with activities. Connected the learners' learning experience to current and past experiences. Met with the lead teacher to create and select activities from Project Connect to use with students. The lead teacher was new to the district. Much of the time was spent on students IEP goals, benchmark goals for reading and math and grouping students with matching developmental needs. The Lead teacher had experience with self-contained classroom and very little experience collaborating with the regular classroom teacher. I was able to collaborate with the teacher on their unit on energy and another classroom teacher on their wood unit. I did keep a jour- nal on the Investigation Math and Literacy by Design Reading curricular material to show that science could be integrated with other subjects." [Paraeducator, \#2]

"To achieve my goal of enhancing my collaborative relationship with my science and lead teachers I made a Power Point presentation of the activities and skills we experienced during the project (second year). Throughout the school year I continued to mention what we had learned and share the materials I received with my science teachers and lead teacher. I met with my school principal and from that meeting arraigned to fill a display case with some of the materials we received from the Engineering Department. This display included material on the Engineering Department itself and on engineering occupations our students might find interesting along with the tower that my team constructed. I also met with the science teachers at my school and presented the materials we were given and showed a Power Point that went over our experience. I used the "Key Concept" strategy in helping all the students that I worked with but I found it worked particularly well with my Hearing Impaired students in both Science and Social Studies." [Paraeducator, \#3]

\section{SUMMARY AND CONCLUDING DISCUSSION}

Middle level science teachers increased their ability to explain science concepts through engineering projects and formed collaborative partnerships with paraeducators. Teachers altered their perceptions of the role paraeducators have in supporting implementation of the science curriculum. Paraeducators de- 
Vol. 17, No. 1 - 2013

Journal of Science Education for Students with Disabilities veloped the ability to directly assist in delivering inquiry-based science to students with special needs. Follow-up interviews with science teachers reveal improvement in state assessments as a direct result of including paraeducators in a true collaboration to integrate engineering concepts. Middle level science teachers cited gains in critical thinking and problem solving skills among students supported by paraeducators. This collaboration impacted 390 middle level students in an urban district.

Although institutionalization of the professional development requires continued support, the design of the professional development equipped science teachers and paraeducators to become "leaders" in reform within their schools. This study demonstrates how a professional development model embedded with ongoing assessment of implementation informs change in science teaching in classrooms in an urban district. The study goes beyond traditional models of providing separate professional development for teachers and paraeducators. The change process was facilitated through a professional development model designed to identify and address factors impeding science teacher and paraeducator collaboration and ultimately student science achievement.

\section{RECOMMENDATIONS FOR IMPLE- MENTATION AND FUTURE STUDIES}

In future studies, it would be optimal for paraeducators to have a consistent placement during the academic year with a science teacher. It was noted that paraeducators have frequent even daily changes in classroom assignments. Paraprofessionals with experience in science teaching should have preference for supporting middle level science teachers and students. Administrative support is critical to sustaining professional development efforts during summer science institutes. Principal involvement in professional development by attending sessions to gain a deeper-level understanding will change the climate for science instruction in the middle school. Finally, sustainment of the TPC model is achieved through principals, science teachers, and paraeducators developing an action plan to improve and support student science achievement.

\section{REFERENCES}

Banilower, E., Boyd, S., Pasley, J. \& Weiss, I. (2006). The capstone report: Lessons from a decade of mathematics and science reform. available fromhttp://www. horizon-research.com/reports/2006/capstone.php.

Bittel, K. \& Hernandez, D. (2006). Differentiated Assessment. Science Scope, 49-51.

Cantrell, P., Pekcan, G., Itani, A., VelasquezBryant, N. (2005). Using engineering design curriculum to close science achievement gaps for middle school students. 35th ASEE/IEE

Frontiers in Education Conference, Indianapolis, IN.

Enochs, L. G., \& Riggs, I. M. (1990). Further development of an elementary science teaching efficacy belief instrument: A preservice elementary scale. School Sci- 
ence \& Mathematics, 90, 694-706.

Guskey, T. (2000). Evaluating professional development. Thousand Oaks, CA: Corwin Press.

National Commission on Teaching and America's Future. (2010). STEM teachers in professional learning communities: A knowledge synthesis. New York.

National Council for Accreditation of Teacher Education (NCATE). 2008. Professional Standards for the Accreditation of Teacher Preparation Institutions. Washington, DC: Author.

National Research Council (NRC) (1996). National Science Education Standards. Washington, D.C.: National Academy Press.
Nevin, A., Villa, R., \& Thousand, J. (2009). A guide to co-teaching with paraeducators: Practical tips for k-12 educators. Thousand Oaks, CA: Corwin Press.

Piburn, M., Sawada, D., Falconer, K., Turley, J. Benford, R., Bloom, I. (2000). Reformed Teaching Observation Protocol (RTOP). ACEPT IN-003. The RTOP rubric form, training manual and reference manual containing statistical analyses, available from: http://PhysicsEd.BuffaloState.Edu/AZTEC/rtop/RTOP_full/PDF/

Strauss, A. L., \& Corbin, J. (1991). Basics of Qualitative Research: Grounded Theory Procedures and Techniques. Newbury Park, California: Sage Publications, Inc.

\section{BIOGRAPHICAL STATEMENTS}

Kimberly Staples (kstaples@ ksu.edu) completed her Ph.D. in Curriculum and Instruction, Science Education, from The University of Alabama, Tuscaloosa, AL. Dr. Staples received her B.S. degree (Zoology) from Howard University, and M.A.Ed. and Ed.S. degrees (Biology Education) from University of Alabama at Birmingham. As a NASA/NOVA research fellow she published findings on the effects of non- traditional undergraduate science courses on science teacher professional development and student performance.

As an associate professor at Kansas State University she teaches graduate and undergraduate secondary science education courses. Dr. Staples researches alternative science conceptions and pathways to science success for ALL learners. She organized a col- laboration among teachers in Kansas, Cameroon, and Saudi Arabia to investigate linguistic and cultural influences on science learning. She is the Principal Investigator of Project SHIFTS, a federally funded teacher quality grant designed to increase conceptual understanding and higher level reasoning among middle level and secondary biology and physics students. 